\title{
Estrutura interna e ação eleitoral de uma agremiação oposicionista no contexto da Era Vargas: o caso do Partido Social Nacionalista (Estado do Paraná, 1934)
}

\section{Internal structure and electoral action of an oppositionist party in the context of Vargas Era: the case of the Nationalist Social Party (State of Paraná, 1934)}

\author{
Sandro Aramis Richter Gomes ${ }^{*}$ \\ https://orcid.org/0000-0002-6790-4958
}

\begin{abstract}
Resumo
Neste artigo é realizada uma investigação sobre a composição social do núcleo dirigente e das chapas de candidatos do Partido Social Nacionalista (PSN), no ano de 1934. Tal agremiação funcionou no Estado do Paraná. Por meio de um estudo de caso, o propósito deste trabalho é produzir conhecimento acerca das formas de ação eleitoral de partidos estaduais de oposição nos anos posteriores à Revolução de 1930. Primeiro, cumpre demonstrar que essa agremiação contou com a presença de uma nova geração de políticos. Uma parcela dos membros dessa geração era eleitoralmente mais competitiva do que os políticos veteranos. Segundo, é destacado que o PSN foi o refúgio de parentelas que haviam perdido influência no cenário político paranaense nos anos finais da Primeira República. 0 terceiro argumento afirma que essa agremiação não se tornou a principal força eleitoral da oposição paranaense. Nesse contexto, os políticos governistas da época da Primeira República formaram o grupo oposicionista mais competitivo do estado.
\end{abstract}

Palavras-chave: Eleições parlamentares; Elites políticas; Partidos estaduais.

\begin{abstract}
The article analyzes the social composition of the ruling core and the lists of candidates of the Nationalist Social Party (PSN) in 1934. This party existed in the state of Paraná. Through a case study, the purpose of this paper is to produce knowledge about the forms of electoral action of regional opposition parties in the years following the Revolution of 1930. First, evidenced is given that this party was attended by a new generation of politicians. A portion of the members of this generation were more electorally more competitive than
\end{abstract}

\footnotetext{
*Doutor em História pela Universidade Federal do Paraná (UFPR). Atualmente realiza estágio de pós-doutorado no Programa de Pós-Graduação em História da UFPR. E-mail: argomes8@gmail.com
} 
the veteran politicians. Second, it should be noted that the PSN was the refuge of relatives who had lost influence on the political scene in Paraná in the final years of the First Republic. The third argument states that this party has not consolidated itself as the main electoral force of the Paraná opposition. In this context, the ruling politicians of the time of the First Republic formed the most competitive opposition group in that state.

Keywords: Parliamentary elections; Political elites; Regional political parties.

\section{Introdução}

Neste artigo é realizada uma investigação sobre o perfil social dos dirigentes e candidatos do Partido Social Nacionalista (PSN). Tal agremiação funcionou no Estado do Paraná, de 1934 a 1937. Ela apresentou candidaturas em eleições ocorridas nos anos de 1934 e 1935. A composição do seu diretório central não experimentou significativa renovação nos anos seguintes à criação do partido.

Ao tempo de sua fundação, o PSN pertencia ao campo oposicionista. Por meio de um estudo de caso, este artigo tem o objetivo de produzir conhecimento acerca das formas de organização interna e de ação eleitoral dos partidos de oposição surgidos no Brasil durante o Governo Provisório de Getúlio Vargas (1930-1934). Nesse âmbito, os resultados do presente trabalho permitem um entendimento sobre os impactos da Revolução de 1930 em um quadro partidário regional.

Há três argumentos fundamentados nesta investigação. Primeiro, é demonstrado que o PSN foi uma agremiação que propiciou a emergência de uma geração de políticos novatos na cena partidária do Paraná. Trata-se de evidenciar que, nesse estado, no início dos anos 1930, era expressivo o contingente de novatos que integraram a cúpula da grei. Nesse particular, cumpre destacar que o PSN foi o partido por meio da qual um conjunto de militares conquistou maior projeção nas lides políticas.

O segundo argumento salienta que essa agremiação tornou-se o refúgio para parentelas que vivenciaram o declínio de sua força eleitoral nos anos finais da Primeira República. Compete evidenciar que um dos limites da renovação do campo oposicionista do Paraná consistiu na existência de famílias que conseguiram se acomodar em funções de destaque nos partidos instituídos nesse estado. Nesse contexto, o PSN foi uma agremiação em que 
os novatos e veteranos da política participaram tanto do diretório central quanto das chapas de candidatos. No início dos anos 1930, uma parcela desses veteranos mantinha-se eleitoralmente competitiva.

O terceiro argumento salienta que tal partido não formou uma relevante base eleitoral. Os resultados das eleições das quais participou demonstram que essa grei não teve êxito na tarefa de se consolidar como a principal agremiação da oposição paranaense. A fusão com o partido governista do estado evidenciou que o PSN não desenvolveu, de forma ininterrupta, o combate ao governismo. A demonstração desse argumento permite asseverar que, no Paraná, no início da Era Vargas, os políticos destituídos de seus cargos pela Revolução de 1930 possuíam a força eleitoral necessária para liderarem o campo da oposição.

Os estudos sobre a atuação de partidos políticos no Brasil, no começo dos anos 1930, têm experimentado avanços. Um desses avanços reside no reconhecimento da elevação do grau de competividade das disputas eleitorais. Dessa forma, a historiografia tem destacado que a vida política nos estados, na referida época, conheceu mudanças em relação à situação vigente na Primeira República.

Uma mudança diz respeito ao fato de que o jogo partidário dos estados se tornou caracterizado pela presença de distintas correntes políticas. Houve a extinção de um cenário em que os partidos governistas competiam apenas com um partido de oposição, o qual comumente se extinguia após uma derrota eleitoral. ${ }^{1}$

Outro avanço nas análises sobre o cenário político do Brasil dos anos 1930 consiste na análise da acomodação de chefes partidários da Primeira República em esferas administrativas no decorrer da Era Vargas. Tal linha de abordagem propicia um entendimento a respeito das diferenças entre as elites regionais no que concerne à capacidade de se adaptarem às mudanças políticas. ${ }^{2}$

\footnotetext{
${ }^{1}$ Acerca de tal corrente de análise, ver COSTA, Luiz Domingos; MASSIMO, Lucas; PERISSINOTTO, Renato Monseff. Oligarquia Competitiva e Profissionalização Política: o caso dos senadores brasileiros na Primeira República (1889-1934). Dados, Rio de Janeiro, v. 60, n. 1, 2017, p. 79-110; LAPUENTE, Rafael Saraiva. A luta pelo poder: a política gaúcha em perspectiva (1934-1937). Dissertação (Mestrado em História). Pontifícia Universidade Católica do Rio Grande do Sul. Porto Alegre, 2016; SILVA, Estevão; SILVA, Thiago. Eleições no Brasil antes da democracia: o Código Eleitoral de 1932 e os pleitos de 1933 e 1934. Revista de Sociologia e Política. Curitiba, v. 23, n. 56, 2015, p. 75-106.

${ }^{2}$ Ver CODATO, Adriano Nervo. Elites e instituições: uma análise contextual do Estado Novo. Tese (Doutorado em Ciência Política). Universidade Estadual de Campinas. Campinas, 2008; DAGOSTIM, Maristela Wessler. A República dos Conselhos: um estudo sobre a transformação do perfil da elite política paranaense (1930-1947). Dissertação (Mestrado em Ciência Política). Universidade Federal do Paraná. Curitiba, 2011.
} 
Cumpre destacar, por outro lado, três limitações quanto ao estado da arte sobre o jogo partidário dos estados no contexto dos anos 1930. Uma limitação decorre do incipiente conhecimento a respeito do perfil social dos dirigentes das agremiações. Tal situação impõe obstáculos para reconhecer o grau de renovação de lideranças políticas após o fim da Primeira República. Ela também gera dificuldades para identificar as posições ocupadas pelos políticos veteranos no interior dos novos partidos estaduais.

A segunda limitação deriva da ausência de uma investigação sistemática sobre resultados eleitorais. Desse modo, mantém-se pouco desenvolvido o conhecimento acerca do desnível entre a força política dos partidos de situação e de oposição. Permanecem pouco avançados os estudos acerca das flutuações do desempenho eleitoral das agremiações surgidas no início dos anos 1930. Há, pois, pouca ênfase na compreensão dos fatores e impactos políticos dessas flutuações. ${ }^{3}$

Ao mesmo tempo, a historiografia não tem avançado na compreensão das diferenças entre as estratégias eleitorais adotadas pelos oposicionistas no decorrer da Primeira República e do Governo Provisório. Conforme salientado ao longo desta abordagem, o recrutamento de candidatos em distintos grupos profissionais foi inerente às estratégias aplicadas pelos partidos de oposição do Paraná no pleito de 1934.

A terceira limitação diz respeito ao estudo da vida interna dos partidos estaduais de oposição. Permanece pouco avançada análise dos limites da ação eleitoral dessas agremiações. Mantém-se em estágio inicial o entendimento das diferenças, no interior dos partidos de oposição, acerca do grau competividade eleitoral dos veteranos e dos novatos. Ao mesmo tempo, há pouca ênfase no estudo sobre a origem social dos indivíduos que, nos anos 1930, se acomodaram na condição de lideranças regionais da oposição.

Em suma, é episódica a produção de análises referentes à formação de agremiações estaduais que atuaram como oposicionistas. ${ }^{4}$ Presentemente, o principal avanço nos estudos sobre partidos políticos é concernente à atuação que elas desenvolveram em instituições como a Câmara dos Deputados. ${ }^{5} \mathrm{De}$

\footnotetext{
${ }^{3}$ Ver NOLL, Maria Izabel; TRINDADE, Helgio (Org.). Estatísticas eleitorais do Rio Grande da América do Sul: 1823-2002. Porto Alegre: Ed. da UFRGS, 2004.

${ }^{4}$ PRADO, Maria Lígia Coelho. A democracia ilustrada: o Partido Democrático de São Paulo, 1926-1934. São Paulo: Ática, 1986; RAMOS, Plínio de Abreu. Os partidos paulistas e o Estado Novo. Petrópolis: Vozes, 1980; SPINELLI, José. Getúlio Vargas e a oligarquia potiguar, 1930-45. Natal: Ed. da UFRN, 2010.

${ }^{5}$ MOURELLE, Thiago Cavaliere. Guerra pelo poder: a Câmara dos Deputados confronta Vargas (1934-1935). Tese (Doutorado em História). Universidade Federal Fluminense. Niterói, 2015.
} 
todo modo, nota-se que as análises concernentes à vida interna dos partidos em tal época permanecem marcadas pelo caráter panorâmico..$^{6}$ Os estudos históricos são inclinados à construção de sínteses que não comportam o estudo dos fatores da consolidação e do esgotamento da força eleitoral das agremiações que existiram nos anos $1930 .^{7}$

Em última análise, permanece pouco avançado o entendimento acerca das formas de gestão partidária e dos limites da renovação dos quadros políticos nos estados. De sua parte, o presenta trabalho busca evidenciar que as distinções sociais que existiram entre as lideranças e candidatos do PSN são indícios das mudanças, no âmbito do Estado do Paraná, da composição do quadro partidário e das estratégias eleitorais das agremiações de oposição.

Nesta investigação são empregados procedimentos de análise inspirados na prosopografia. ${ }^{8}$ Tal linha de abordagem possibilita reconhecer elementos convergentes das carreiras políticas dos indivíduos que atuaram como próceres da oposição paranaense nos anos 1930. Ao mesmo tempo, essa investigação permite salientar a natureza do vínculo que tais indivíduos mantiveram com a ordem governista do Paraná ao tempo da Primeira República. ${ }^{9}$

\section{A fundação do PSN e a composição de seu núcleo dirigente: a dissidência no grupo de apoiadores da Revolução de 1930}

O PSN foi implantado no Paraná em abril de $1934 .{ }^{10}$ O estudo sobre a estrutura e o funcionamento dessa grei exige o conhecimento do contexto político em que essa agremiação surgiu. Para o desenvolvimento dessa abordagem, cumpre fundamentar três constatações.

\footnotetext{
${ }^{6}$ NICOLAU, Jairo. As eleições no Brasil: do Império aos dias atuais. Rio de Janeiro: Jorge Zahar, 2012; PORTO, Walter Costa. $O$ voto no Brasil: da Colônia à $6^{a}$ República. Rio de Janeiro: Topbooks, 2002.

${ }^{7}$ ACHIAMÉ, Fernando. O Espírito Santo na Era Vargas (1930-1937). Rio de Janeiro: Ed. da FGV, 2010; OLIVEIRA, Ricardo Costa de (Org.). A construção do Paraná moderno: políticos e política no Governo do Paraná de 1930 a 1980. Curitiba: Ed. da Secretaria de Estado de Ciência e Tecnologia, 2004.

${ }^{8} \mathrm{CHARLE}$, Christophe. A prosopografia ou biografias coletivas: balanço e perspectivas. In: HEINZ, Flávio (Org.). Por outra história das elites. Rio de Janeiro: Ed. FGV, 2006, p. 41-54; STONE, Lawrence. Prosopografia. Revista de Sociologia e Política. Curitiba, v. 19, n. 39, p. 115-137, 2011.

${ }^{9}$ As informações empregadas nesta análise são provenientes de jornais paranaenses e fluminenses. A utilização de periódicos possibilita a coleta de informações referentes ao preenchimento de cargos comissionados no Paraná desde o início da Primeira República. O estudo dessas fontes também propicia a obtenção de informações sobre os resultados de eleições ocorridas no Paraná nos anos de 1933 e 1934. Essas fontes estão disponíveis para consulta no sítio eletrônico da Hemeroteca Digital Brasileira: <memoria.bn.br>

${ }^{10}$ Diário da Tarde, Curitiba, 17 abr. 1934, p. 1.
} 
Primeiro, cabe mencionar que, ao tempo do Governo Provisório, foram criados outros três partidos que empregavam a sigla PSN. A primeira tentativa de criação de um Partido Social Nacionalista ocorreu no ano 1932. O propósito dos seus fundadores era implantar uma agremiação nacional. Essa grei era liderada por políticos veteranos de Minas Gerais, a exemplo do ex-presidente Artur Bernardes. ${ }^{11} \mathrm{~A}$ duração do partido, contudo, não foi além do primeiro semestre do mencionado ano. ${ }^{12}$ Nessa época, no Piauí, também houve a implantação de uma grei homônima. Ela não sobreviveu para além de tal ano. ${ }^{13} \mathrm{Em} 1933$, por fim, surgiu no Rio Grande do Norte uma agremiação também denominada PSN. ${ }^{14}$

A diferença entre o PSN-RN e o PSN-PR é que o primeiro, desde o momento de sua fundação, pertenceu ao campo situacionista de seu estado. Foram apenas essas duas unidades do PSN que formaram uma base eleitoral suficiente para eleger candidatos a cargos como o de deputado federal. ${ }^{15}$ Ambos os partidos foram fundados em uma época em que os partidos estaduais ainda permaneciam eleitoralmente fortes. No entanto, as agremiações nacionais começavam a se organizar. ${ }^{16}$

No período em tela, os partidos homônimos dispunham de autonomia para conceberem seu modelo de organização interna, bem como para formularem o seu repertório de propostas. No início dos anos 1930, surgiram oito agremiações que utilizavam a denominação de Partido Social Democrático (PSD). A semelhança entre esses partidos estaduais reside no fato de que apoiavam o Governo Vargas. Contudo, eles eram independentes entre si do ponto de vista administrativo. ${ }^{17}$

Segundo, trata-se de mencionar que o PSN do Paraná permaneceu a maior parte de sua existência como um partido de oposição ao governador

\footnotetext{
${ }^{11}$ Diário da Tarde, Curitiba, 19 abr. 1932, p. 1.

${ }^{12}$ RAMOS, Plínio de Abreu. O PSD mineiro. Belo Horizonte: Itatiaia, 1993.

${ }^{13}$ NOHLEN, Dieter. Elections in the Americas: a Data Handbook. Vol. 2. Oxford: Oxford University Press, 2005.

${ }^{14}$ MARIZ, Marlene da Silva. A Revolução de 30 no Rio Grande do Norte. Brasília: Ed. Senado Federal, 1984.

${ }^{15}$ Acerca da atuação política de membros do PSN-RN, ver MOURELLE, Guerra pelo poder... op. cit.

${ }^{16}$ Respeitante ao contexto da criação das agremiações nacionais nos anos 1930, sobretudo a Ação Integralista Brasileira e a Aliança Nacional Libertadora, ver LEVINE, Robert M. O Regime de Vargas: os anos críticos (1934-1938). Rio de Janeiro: Nova Fronteira, 1980.

${ }^{17}$ Cumpre salientar que, entre os anos de 1932 e 1933, houve a implantação de agremiações denominadas de PSD nos seguintes estados: Bahia, Ceará, Espírito Santo, Maranhão, Paraná, Pernambuco, Rio Grande do Norte e Sergipe. Acerca do funcionamento de PSD em estados do Nordeste e do Sudeste, nos anos 1930, ver PANDOLFI, Dulce Chaves. A trajetória do Norte: uma tentativa de ascenso político. In: GOMES, Ângela Maria de Castro (Coord.). Regionalismo e centralização política: partidos e Constituinte nos anos 30. Rio de Janeiro: Nova Fronteira, 1980, p. 339-425; RAMOS, O PSD mineiro... op. cit.
} 
Manuel Ribas (1873-1946). Em meados de 1937, os líderes do PSN se aproximaram dos situacionistas e promoveram a fusão desse partido com o PSD, que era a agremiação dominante no estado. Por consequência, foi criado o Partido Nacionalista Democrático (PND). Tal fusão não contou com a aprovação unânime dos correligionários do PSD. ${ }^{18}$

A implantação do Estado Novo, em novembro do mencionado ano, ocasionou a dissolução do PND. O episódio da fusão partidária evidencia que Manuel Ribas exercia marcante ingerência sobre o partido situacionista. Ele liderou as articulações para efetivar tal fusão. Em resumo, o chefe do Executivo Estadual atuava como um dirigente partidário. ${ }^{19}$

Terceiro, cumpre mencionar que a criação do PSN não significou a primeira experiência de seus chefes na gestão de um partido político. De 1931 a 1933, tais líderes pertenceram ao Partido Liberal Paranaense (PLP). Essa agremiação era formada por apoiadores de primeira hora da candidatura presidencial de Vargas, em 1930. Portanto, a implantação dessa grei teve o propósito de formalizar a aliança política entre os correligionários desse governante. O PLP também apoiava a gestão do interventor federal Mário Tourinho (1871-1964), que permaneceu nesse cargo de 1930 a $1931 .^{20}$

Essa agremiação migrou para o campo da oposição em $1932 .{ }^{21}$ Um motivo capital para essa migração consistiu na exoneração de Tourinho do cargo de interventor. O sucessor de tal militar foi o citado Manuel Ribas, que permaneceu à frente do Governo do Paraná até o ano de $1945 .{ }^{22}$

Em 1933, o PLP participou de seu único pleito. A grei apresentou uma chapa de quatro candidatos à Assembleia Nacional Constituinte e conseguiu eleger um postulante. Tal desempenho foi mais expressivo do que o obtido pelo Partido Republicano Paranaense (PRP), o qual congregava os políticos destituídos pela Revolução de 1930. O PRP também lançou uma chapa completa nessa ocasião, mas todos os seus candidatos foram derrotados. Nessa oportunidade, a votação angariada pelos partidos estaduais do Paraná foi a seguinte: PSD, 14.888; PLP, 6.480; PRP, 2.789..$^{23}$

\footnotetext{
${ }^{18}$ Diário da Tarde, Curitiba, 25 set. 1937, p. 2.

${ }^{19}$ Diário da Tarde, Curitiba, 10 jul. 1937, p. 1.

${ }^{20}$ Concernente a tal momento político, ver OLIVEIRA, Ricardo Costa de. Nota sobre a política paranaense de 1930 a 1945. Revista de Sociologia e Política. Curitiba, v. 1, n. 9, p. 47-56, 1997.

${ }^{21}$ Correio do Paraná, Curitiba, 9 abr. 1932, p. 1.

${ }^{22}$ Acerca do contexto em que Manuel Ribas exerceu o posto de governador do Paraná, ver DAGOSTIM, A República dos Conselhos... op. cit.

${ }^{23}$ O Dia, Curitiba, 18 mai. 1933, p. 1.
} 
Conforme demonstrado no decorrer deste artigo, o grupo político que criou o PLP e o PSN não conseguiu se consolidar como a principal força eleitoral da oposição paranaense. Tal grupo não teve êxito na tarefa de promover significativo aumento de seu eleitorado. A perda de sua influência sobre o campo da oposição foi sucedida pela aproximação com os governistas. Em meados de 1934, o PLP foi extinto. Em seguida, os seus antigos líderes criaram o PSN. Esse partido também era constituído por dissidentes do PSD. ${ }^{24}$ Portanto, em tal ano o grupo situacionista do Paraná estava cindido.

Foi nessa época que se consolidou um quadro partidário que permaneceu em vigor até o primeiro semestre de 1937. Nesse cenário, a agremiação governista era representada pelo PSD. Os dissidentes do situacionismo estavam integrados ao PSN. Por fim, os políticos que aturam como governistas ao tempo da Primeira República pertenciam à União Republicana Paranaense (URP). ${ }^{25}$

Em 1934, um anseio capital dos chefes PSN era consolidar a posição do partido como o principal grupo de oposição ao Governo do Paraná. Uma iniciativa direcionada a concretizar esse objetivo foi ampliar a capilaridade social da grei. O PSN, assim, não deveria se limitar à categoria de agremiação liderada por militares que apoiaram a Revolução de 1930. Oriundos dos partidos da Primeira República, os políticos veteranos eram personagens que os fundadores do PSN buscaram incorporar ao seu rol de correligionários. ${ }^{26}$

A primeira etapa da realização desse propósito consistiu na distribuição dos cargos do diretório da agremiação. Essa distribuição promoveu a formação de um núcleo dirigente socialmente heterogêneo. 0 estudo das diferenças entre os percursos políticos dos integrantes da cúpula do PSN requer a atenção às informações presentes no Quadro 1.

\footnotetext{
${ }^{24}$ Diário da Tarde, Curitiba, 3 abr. 1934, p. 1.

${ }^{25} \mathrm{~A}$ URP foi criada após a dissolução do PRP. Em larga medida, o surgimento da URP foi decorrente do retorno à cena política de próceres do situacionismo paranaense da época da Primeira República. Um desses próceres era o ex-governador Caetano Munhoz da Rocha (1873-1944). Diário da Tarde, Curitiba, 3 jul. 1934, p. 1.

${ }^{26}$ Essa incorporação não se limitou aos primeiros meses de 1934, que foi a época de fundação da grei. Ela prosseguiu durante o segundo semestre de tal ano. Em agosto, por exemplo, a presidência do diretório do PSN na cidade de Curitiba foi conferida ao bacharel Manuel de Alencar Guimarães (1865-1940). Diário da Tarde, Curitiba, 1 set. 1934, p. 1. Ele fora uma das principais lideranças do Partido Republicano Paranaense ao tempo da Primeira República. Contudo, não participou das articulações direcionadas a reativar essa agremiação, no início dos anos 1930. O PSN, portanto, buscou o apoio tanto de dissidentes do PSD quanto de membros históricos do PRP. Acerca do quadro partidário paranaense ao tempo da Primeira República, ver GOULART, Mônica Helena Harrich Silva. Classe dominante e jogo político na Assembleia Legislativa Paranaense (1889-1930). Tese (Doutorado em Sociologia). Universidade Federal do Paraná. Curitiba, 2008.
} 
Quadro 1: Atuação política e profissional dos membros do Diretório Central do Partido Social Nacionalista (1934)

\begin{tabular}{|c|c|c|c|c|c|c|}
\hline Nome & Ocupação & $\begin{array}{c}\text { Função no } \\
\text { diretório }\end{array}$ & \begin{tabular}{|c|} 
Total de mandatos \\
no Poder Executivo \\
(Primeira República)
\end{tabular} & $\begin{array}{l}\text { Total de mandatos } \\
\text { no Poder Legislativo } \\
\text { (Primeira República) }\end{array}$ & $\begin{array}{l}\text { Total de nomeações } \\
\text { para cargos públicos } \\
\text { (Primeira República) }\end{array}$ & $\begin{array}{l}\text { Total de nomeações } \\
\text { para cargos públicos } \\
\text { (Governo Provisório) }\end{array}$ \\
\hline $\begin{array}{c}\text { Joaquim Pereira } \\
\text { de Macedo }\end{array}$ & Industrial & Presidente & 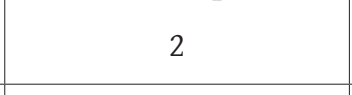 & 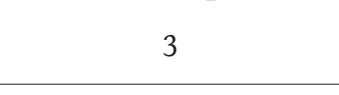 & 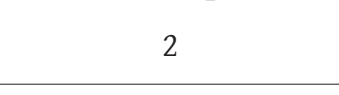 & 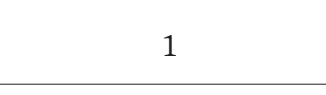 \\
\hline $\begin{array}{l}\text { Mário Monteiro } \\
\text { Tourinho }\end{array}$ & Militar & Vice-presidente & 0 & 0 & 0 & 1 \\
\hline $\begin{array}{c}\text { Catão Menna } \\
\text { Barreto Monclaro }\end{array}$ & Militar & Secretário & 0 & 0 & 0 & 1 \\
\hline $\begin{array}{c}\text { Benedito de Assis } \\
\text { Corrêa }\end{array}$ & Militar & $\begin{array}{l}\text { Diretor da } \\
\text { Secretaria }\end{array}$ & 0 & 0 & 0 & 0 \\
\hline $\begin{array}{c}\text { Eurico Pereira de } \\
\text { Macedo }\end{array}$ & $\begin{array}{c}\text { Acadêmico de } \\
\text { Direito }\end{array}$ & $\begin{array}{l}\text { Auxiliar de } \\
\text { Secretaria }\end{array}$ & 0 & 0 & 0 & 0 \\
\hline $\begin{array}{l}\text { Alfredo Dulcídio } \\
\text { Pereira }\end{array}$ & \begin{tabular}{|c|} 
Servidor \\
Público \\
Estadual \\
\end{tabular} & Tesoureiro & 0 & 0 & 0 & 0 \\
\hline $\begin{array}{l}\text { Benjamin Lins de } \\
\text { Albuquerque }\end{array}$ & Advogado & $\begin{array}{c}\text { Delegado do } \\
\text { PSN no Tribunal } \\
\text { Regional Eleitoral }\end{array}$ & 0 & 0 & 2 & 3 \\
\hline $\begin{array}{l}\text { Marcelino } \\
\text { Nogueira Júnior }\end{array}$ & Advogado & $\begin{array}{c}\text { Delegado do } \\
\text { PSN no Tribunal } \\
\text { Regional Eleitoral } \\
\end{array}$ & 0 & 4 & 2 & 0 \\
\hline $\begin{array}{l}\text { João Ribeiro de } \\
\text { Macedo Filho }\end{array}$ & Advogado & Consultor Jurídico & 0 & 0 & 2 & 1 \\
\hline Luís Quadros & Advogado & Consultor Jurídico & 0 & 0 & 0 & 0 \\
\hline $\begin{array}{l}\text { Alceu do Amaral } \\
\text { Ferreira }\end{array}$ & Médico & Membro efetivo & 0 & 0 & 0 & 0 \\
\hline $\begin{array}{l}\text { Emílio Muller } \\
\text { Neiva de Lima }\end{array}$ & $\begin{array}{c}\text { Engenheiro } \\
\text { Civil }\end{array}$ & Membro efetivo & 0 & 0 & 0 & 2 \\
\hline $\begin{array}{c}\text { Francisco José } \\
\text { Guérios }\end{array}$ & Médico & Membro efetivo & 0 & 0 & 0 & 1 \\
\hline $\begin{array}{c}\text { Francisco } \\
\text { Martins Franco }\end{array}$ & Médico & Membro efetivo & 0 & 0 & 0 & 1 \\
\hline Roberto Glasser & Agropecuarista & Membro efetivo & 0 & 1 & 0 & 1 \\
\hline
\end{tabular}

Fontes: A República (PR); Diário da Tarde (PR); Diário do Comércio (PR); Gazeta do Povo (PR); O Dia (PR). 
A análise desse Quadro permite salientar que, em 1934, a cúpula do PSN era marcada pela coexistência de quatro categorias de correligionários. Tais indivíduos se diferenciavam em virtude das posições políticas que sustentaram no decorrer da Primeira República. Uma categoria de dirigentes da grei era constituída pelos militares. Tratava-se de um grupo cujos membros principiaram a atuar na vida política no contexto da campanha presidencial de Getúlio Vargas. Nesse âmbito, cumpre salientar que eles desempenharam posições centrais na administração pública paranaense nos meses que se seguiram à Revolução de 1930. O general Mário Tourinho (1871-1864), por exemplo, foi interventor federal do Paraná de 1930 a $1931 .^{27}$

Os militares ligados ao PSN foram personagens capitais na montagem do PLP, o primeiro partido governista criado no Paraná após o mencionado evento político. $O$ envolvimento na estruturação dessa grei lhes possibilitou um treinamento em tarefas como a gestão de diretórios partidários e o recrutamento de filiados. ${ }^{28}$ Assim, cumpre salientar que os aliados de Mário Tourinho tiveram êxito na tarefa de levar o PLP para o campo da oposição no momento em que começaram a perder espaço na administração estadual para o grupo político de Manuel Ribas.

Esse protagonismo dos militares significou uma mudança em relação ao cenário político que vigorou no estado durante a Primeira República. Nas quatro primeiras décadas republicanas, os militares exerceram apenas circunstancialmente mandatos eletivos. Foi pouco relevante o contingente de militares paranaenses que desempenharam os cargos de deputado estadual e deputado federal. ${ }^{29}$

Em tal época, eles também não ocuparam posições de destaque nos partidos de oposição e situação que funcionaram no Paraná. Nesse estado, os militares conseguiram um acesso episódico às instituições políticas nas épocas em que se integraram à ordem governista. Houve apenas uma ocasião em que um militar de oposição conseguiu obter um mandato na Câmara dos Deputados pelo Paraná. ${ }^{30}$ Tratava-se do general Alberto Ferreira de Abreu

\footnotetext{
${ }^{27}$ Acerca da atuação de Mário Tourinho no cargo de interventor, ver PILOTO, Valfrido. Quando o Paraná se levantou como uma nação. Curitiba: Instituto Histórico, Geográfico e Etnográfico Paranaense, 1982.

${ }^{28}$ Correio do Paraná, Curitiba, 20 out. 1932, p. 1.

${ }^{29}$ De 1891 a 1930, houve apenas sete militares que se elegeram para o cargo de deputado estadual do Paraná. Ver GOULART, Classe dominante... op. cit. Ao mesmo tempo, houve apenas três militares que, no mencionado período, foram eleitos deputados federais pelo Paraná. Acerca do perfil político e social dos eleitos para tal cargo na época da Primeira República, ver OLIVEIRA, Ricardo Costa de. O silêncio dos vencedores: genealogia, classe dominante e Estado do Paraná (1853-1930). Curitiba: Moinho do Verbo, 2001.

${ }^{30} \mathrm{Em} \mathrm{1890}$, dois militares governistas foram eleitos deputados federais pelo Paraná: Belarmino Augusto de Mendonça Lobo e Marciano Botelho de Magalhães. Eles se candidataram em um contexto no qual as
} 
(1853-1933), eleito deputado federal em 1915. Tal êxito não decorreu da força eleitoral da oposição estadual. Ele foi derivado da não apresentação de uma chapa completa de candidatos pelo partido governista. ${ }^{31}$ Nos anos posteriores à Revolução de 1930, a oposição paranaense não necessitou mais de artifícios como a apresentação de uma lista incompleta de candidatos governistas para conseguir eleger um candidato. Houve, pois, o fortalecimento eleitoral do campo oposicionista.

Para corroborar tal afirmação, cabe destacar que, em 1933, no pleito para as quatro vagas de deputado à Assembleia Nacional Constituinte, o PLP lançou chapa completa. A agremiação governista, o PSD, também homologou quatro postulantes. No entanto, esse partido não conseguiu eleger todos os nomes que apresentou. Uma das vagas da bancada paranaense naquela Assembleia foi preenchida pelo tenente-coronel Plínio Tourinho (1882-1950), o oposicionista mais votado. ${ }^{32}$ Conforme demonstrado ao longo deste trabalho, no pleito para a Câmara dos Deputados ocorrido em 1934 esse militar obteve novo mandato e permaneceu como o candidato mais competitivo do seu grupo político. Ou seja, não foi efêmera a demonstração da força eleitoral da oposição estadual.

A segunda categoria de dirigentes do PSN era formada por políticos veteranos que mantiveram ligações com o partido governista que existiu no Paraná na época anterior à Revolução de 1930. O nome mais influente desse grupo era Joaquim Pereira de Macedo (1858-1949), presidente da agremiação. A esse respeito, cumpre salientar que a reorganização do quadro partidário paranaense, no início dos anos 1930, não encerrou uma situação que perdurava desde os anos finais da Primeira República.

Tal situação era marcada pelo afastamento de antigos membros do situacionismo estadual, a exemplo de Joaquim Macedo e Benjamin Lins (18761951), em relação aos líderes do PRP. Foi tal distância que provocou a adesão

\footnotetext{
chapas de deputados estaduais dos partidos de situação e oposição também contavam com a presença de militares. Provenientes do Estado do Rio de Janeiro, Lobo e Magalhães não se enraizaram na vida política paranaense. Eles desempenharam apenas um mandato à Câmara dos Deputados. Acerca dos percursos políticos dos deputados federais do Paraná eleitos nesse contexto, ver ABREU, Alzira Alves de (Coord.). Dicionário histórico-biográfico da Primeira República (1889-1930). Rio de Janeiro: Ed. FGV, 2015.

${ }^{31}$ A eleição de Alberto de Abreu para deputado federal ocorreu em 1915. Em tal ocasião, o partido governista do Paraná apresentou apenas três candidatos. A quarta vaga coube a Abreu, que representava as forças da oposição. De todo modo, ele foi o menos votado entre os candidatos eleitos nessa ocasião. Abreu obteve 6.814 votos. O terceiro colocado, que era ligado aos governistas, angariou 14.417 sufrágios. BRASIL. Anais da Câmara dos Deputados. Rio de Janeiro: Imprensa Nacional, 1916, v. 2, p. 786.
}

${ }^{32}$ Correio do Paraná, Curitiba, 19 mai. 1933, p. 1. 
de ambos à candidatura presidencial de Getúlio Vargas..$^{33}$ Os próceres do PRP não conseguiram reunir a totalidade de seus antigos apoiadores para executar o projeto de reativação da grei. Portanto, nos anos 1920 o grupo político reunido nessa legenda já havia passado por uma cisão.

A terceira categoria de dirigentes da grei era formada por Roberto Glasser (1878-1958). Ele era o único oposicionista histórico que participava da direção do PSN. Ou seja, tratava-se de um indivíduo que não tivera passagens por partidos governistas durante a Primeira República. O longo pertencimento ao campo oposicionista tornou-o eleitoralmente pouco competitivo. A única vitória eleitoral que obteve antes de 1930 foi para o cargo de deputado estadual. Ocorrida em 1913, essa vitória derivou do fato de que o partido governista apresentou uma chapa incompleta de candidatos. ${ }^{34} \mathrm{Em} \mathrm{1930,} \mathrm{contudo,} \mathrm{Glasser}$ não conseguiu se eleger para a Câmara dos Deputados. ${ }^{35}$

De todo modo, nota-se que o PSN incorporou ao seu núcleo dirigente políticos que possuíam longo envolvimento com partidos de oposição e de situação. ${ }^{36}$ Foram integrados a esse núcleo indivíduos que, a exemplo de Roberto Glasser e Joaquim Macedo, estavam familiarizados com a administração de órgãos partidários em âmbito estadual e municipal. O PSN abrigou experientes políticos cujas trajetórias foram marcadas pelo rompimento com agremiações situacionistas. ${ }^{37}$

A quarta categoria, por fim, era formada por indivíduos que começaram a atuar na vida partidária no contexto do Governo Provisório. Esses correligionários do PSN eram indivíduos cujos ascendentes possuíam antigas ligações com partidos políticos. Dentre tais indivíduos, estavam Eurico de Macedo (1913-1978) e João Ribeiro de Macedo Filho (1883-1948). Eles eram,

\footnotetext{
${ }^{33}$ A República, Curitiba, 22 fev. 1930, p. 1.

${ }^{34}$ A República, Curitiba, 18 dez. 1913, p. 2.

${ }^{35}$ A República, Curitiba, 3 abr. 1930, p. 3.

${ }^{36}$ Em 1913, Glasser participou da implantação do diretório estadual do Partido Republicano Liberal, uma agremiação nacional liderada pelo senador baiano Rui Barbosa (1849-1923). Diário da Tarde, Curitiba, 31 out. 1913, p. 2. Glasser era um apoiador desse parlamentar desde a época da Campanha Civilista, em 1910. Tal campanha promoveu a candidatura presidencial de Rui Barbosa. Diário da Tarde, Curitiba, 28 jan. 1910, p. 1. Em 1930, por fim, Glasser foi um líder regional da Aliança Liberal, a qual sustentou a candidatura presidencial de Getúlio Vargas. A República, Curitiba, 22 abr. 1930, p. 1. Portanto, em diferentes contextos políticos Glasser se manteve em uma posição de liderança no campo da oposição paranaense.

${ }^{37} \mathrm{O}$ comerciante Jorge Becher, por exemplo, foi dirigente da Aliança Liberal na cidade de Ponta Grossa. $O$ Dia, Curitiba, 19 nov. 1929, p. 1. Em meados de 1934, ele pertenceu ao diretório do PSD que funcionava nessa cidade. Diário da Tarde, Curitiba, 3 ago. 1934, p. 1. Em seguida, migrou para o Partido Municipal Independente. Becher foi um dos responsáveis por articular a fusão dessa grei com o PSN. Diário da Tarde, Curitiba, 17 ago. 1934, p. 1.
} 
respectivamente, filho e sobrinho de Joaquim Macedo, presidente do PSN. ${ }^{38}$ O pai de Macedo Filho era um negociante que iniciara sua participação no cenário político do Paraná no fim do Segundo Reinado, na qualidade de membro do Partido Conservador. ${ }^{39}$

Assim, o núcleo dirigente do PSN contou com a presença de uma nova geração de políticos. Realizada no decorrer deste artigo, a análise dos Quadros 2 e 3 permite sustentar esta afirmação. De outra parte, cabe reconhecer que havia critérios para a incorporação desses novatos à cúpula do partido. Um dos critérios era a posse de um diploma de ensino superior. Uma parcela desses novatos, por exemplo, tinha formação jurídica. O outro critério era o pertencimento a parentelas que, havia tempos, exerciam marcante influência na vida política do estado. No Paraná, o contexto político posterior à Revolução de 1930 não foi marcado pela redução da capacidade de antigas parentelas continuarem ativas no jogo partidário. ${ }^{40}$

Cumpre salientar que os veteranos que se integraram ao PSN conservaram posições de destaque nesse partido ao longo dos anos 1930. A esse respeito, convém mencionar que Roberto Glasser se tornou presidente da agremiação em 1935. Porém, Joaquim Macedo permaneceu como membro efetivo do diretório central. Nessa ocasião, o veterano Manuel de Alencar Guimarães foi incorporado a tal diretório. ${ }^{41}$ Verifica-se, assim, que o desenvolvimento das atividades eleitorais do PSN foi acompanhado pela consolidação de antigos nomes da política paranaense na condição de dirigentes da grei.

\section{A construção da chapa do PSN para a eleição de deputados estaduais: as origens sociais e as carreiras políticas dos postulantes}

Na presente seção é efetuado o estudo da composição da única chapa de postulantes à Assembleia Legislativa do Paraná lançada pelo PSN. De um lado, cumpre demonstrar que essa agremiação contou com a participação de

\footnotetext{
${ }^{38}$ Concernente às origens da família Macedo, ver NEGRÃO, Francisco. Genealogia paranaense. V. 2. Curitiba: Imprensa Oficial do Paraná, 2004.

${ }^{39}$ Vinculado ao Partido Conservador, o pai de João Ribeiro de Macedo Filho elegeu-se vereador do município paranaense de Campo Largo em 1887. ALVES, Alessandro Cavassin. A Província do Paraná (1853-1889): a classe política, a parentela no Governo. Tese (Doutorado em Sociologia). Universidade Federal do Paraná. Curitiba, 2014, p. 493.

${ }^{40}$ Ver GRANATO, Natália Cristina. O Poder Legislativo Paranaense no contexto da Revolução de 1930: um estudo dos capitais familiares e políticos dos deputados federais e estaduais (1930-1937). Revista do Núcleo de Estudos Paranaenses. Curitiba, v. 1, n. 5, p. 1-39, 2019.
}

${ }^{41} \mathrm{O}$ Dia, Curitiba, 5 set. 1935, p. 5. 
indivíduos pertencentes a distintos grupos profissionais. O lançamento de candidatos novatos pelo PSN era uma forma de o partido ampliar sua capilaridade social. De outro lado, trata-se de corroborar a constatação de que o PSN foi uma agremiação por meio da qual os membros de antigas famílias da elite política paranaense recuperaram um espaço na cena partidária.

A partir do caso do PSN, compete destacar os limites da renovação dos quadros partidários no Paraná dos anos 1930. Para tanto, atente-se às informações inseridas no Quadro 2.

A análise desse Quadro permite a elaboração de três constatações. Primeiro, verifica-se que era pouco relevante o contingente de políticos veteranos incluídos na lista de candidatos a deputado estadual pelo PSN. Desse modo, os dirigentes da grei optaram por construir uma chapa na qual a maior parte dos seus integrantes não possuía experiência no exercício de mandatos eletivos. O exercício eventual de cargos públicos consistiu no limite da participação desses novatos em agências do Estado. Em grande medida, os membros desse grupo não possuíam relevante base eleitoral. Por consequência, o PSN não conseguiu se tornar a principal agremiação oposicionista.

A segunda constatação afirma que uma parcela dos veteranos que se candidataram à Assembleia do Paraná pelo PSN permanecia eleitoralmente competitiva. A votação obtida por tal parcela auxiliou a grei a conquistar uma presença mínima nessa instituição. A reorganização do quadro partidário estadual que ocorreu após a Revolução de 1930 não ocasionou o completo esfacelamento das bases eleitorais formadas pelos veteranos no decorrer da Primeira República.

A despeito do fato de terem permanecido por longos anos distantes das eleições e das instituições políticas, os veteranos ligados ao PSN mantiveram a capacidade de enfrentar lideranças emergentes e assegurar uma participação em instâncias do Poder Legislativo. A semelhança entre tais veteranos residia no fato de que, ao se afastarem dos partidos governistas, atuaram na organização de campanhas eleitorais e na gestão de agremiações oposicionistas. ${ }^{42}$

\footnotetext{
${ }^{42} \mathrm{~A}$ esse respeito, atente-se aos casos dos citados Joaquim Macedo e Manuel de Alencar Guimarães. Em meados dos anos 1910, Macedo saiu do partido situacionista então existente no Paraná. Contudo, recuperou sua força política em virtude da condição de coordenador da campanha presidencial de Vargas no Paraná, em 1930. A República, Curitiba, 10 mar. 1930, p. 3. De sua parte, Alencar Guimarães liderou três agremiações oposicionistas após romper suas relações com os próceres do partido governista. Em 1915, Guimarães foi o chefe da Concentração Republicana, a qual elegeu um deputado federal no seu primeiro ano de funcionamento. De 1915 a 1918, ele foi o presidente do diretório paranaense do Partido Republicano Conservador. Por fim, de 1919 a 1921 presidiu o Partido Autonomista, uma agremiação estadual. A República, Curitiba, 21 jan. 1921, p. 1. Portanto, Guimarães e Macedo tiveram uma ativa participação no cenário político paranaense. Nos anos anteriores à filiação ao PSN, eles já possuíam uma longa atuação no campo da oposição estadual.
} 
Quadro 2: Atuação política e profissional dos candidatos do Partido Social Nacionalista a deputado estadual do Paraná (1934) ${ }^{43}$

\begin{tabular}{|c|c|c|c|c|c|c|c|}
\hline Nome & Ocupação & $\begin{array}{l}\text { Município de } \\
\text { residência }\end{array}$ & $\begin{array}{c}\text { Região do } \\
\text { Estado do } \\
\text { Paraná }\end{array}$ & $\begin{array}{c}\text { Total de mandatos } \\
\text { no Poder Executivo } \\
\text { (Primeira República) }\end{array}$ & $\begin{array}{l}\text { Total de mandatos } \\
\text { no Poder Legislativo } \\
\text { (Primeira República) }\end{array}$ & $\begin{array}{l}\text { Total de nomeações } \\
\text { para cargos públicos } \\
\text { (Primeira República) }\end{array}$ & $\begin{array}{l}\text { Total de nomeações } \\
\text { para cargos públicos } \\
\text { (Governo Provisório) }\end{array}$ \\
\hline Abelardo de Assis & Comerciante & Jacarezinho & $\begin{array}{l}\text { Terceiro } \\
\text { planalto }\end{array}$ & . & ( & . & . \\
\hline $\begin{array}{c}\text { *Alceu do Amaral } \\
\text { Ferreira }\end{array}$ & Médico & Curitiba & $\begin{array}{l}\text { Primeiro } \\
\text { planalto }\end{array}$ & 0 & 0 & 0 & 0 \\
\hline $\begin{array}{c}\text { Álvaro Gonçalves } \\
\text { de Quadros }\end{array}$ & $\begin{array}{c}\text { Acadêmico de } \\
\text { Direito }\end{array}$ & Curitiba & $\begin{array}{l}\text { Primeiro } \\
\text { planalto }\end{array}$ & 0 & 0 & 0 & 0 \\
\hline $\begin{array}{c}\text { *Antônio Couto } \\
\text { Pereira }\end{array}$ & $\begin{array}{c}\text { Servidor } \\
\text { Público Federal }\end{array}$ & Curitiba & $\begin{array}{l}\text { Primeiro } \\
\text { planalto }\end{array}$ & 0 & 0 & 0 & 0 \\
\hline $\begin{array}{c}\text { Antônio da Rocha } \\
\text { Loures Villaça }\end{array}$ & $\begin{array}{c}\text { Serventuário } \\
\text { da Justiça }\end{array}$ & Guarapuava & $\begin{array}{l}\text { Terceiro } \\
\text { planalto }\end{array}$ & 0 & 2 & 2 & 0 \\
\hline Astolfo de Souza & Comerciante & Paula Freitas & $\begin{array}{l}\text { Segundo } \\
\text { planalto }\end{array}$ & 0 & 0 & 0 & 0 \\
\hline Atílio Barbosa & Farmacêutico & Campo Largo & $\begin{array}{l}\text { Primeiro } \\
\text { planalto }\end{array}$ & 0 & 0 & 1 & 1 \\
\hline $\begin{array}{l}\text { Benjamin Lins de } \\
\text { Albuquerque }\end{array}$ & Advogado & Curitiba & $\begin{array}{l}\text { Primeiro } \\
\text { planalto }\end{array}$ & 0 & 0 & 2 & 3 \\
\hline Djalma Lopes & Advogado & Tomazina & $\begin{array}{l}\text { Terceiro } \\
\text { planalto }\end{array}$ & 0 & 1 & 0 & 0 \\
\hline $\begin{array}{c}\text { Emílio Neiva } \\
\text { Müller de Lima }\end{array}$ & $\begin{array}{c}\text { Engenheiro } \\
\text { Civil }\end{array}$ & Curitiba & $\begin{array}{l}\text { Primeiro } \\
\text { planalto }\end{array}$ & 0 & 0 & 0 & 0 \\
\hline $\begin{array}{c}\text { Eurides Santos } \\
\text { Lima }\end{array}$ & Fazendeiro & Jaguariaíva & $\begin{array}{l}\text { Segundo } \\
\text { planalto }\end{array}$ & 0 & 0 & 0 & 0 \\
\hline Felinto Teixeira & $\begin{array}{c}\text { Desembargador } \\
\text { aposentado }\end{array}$ & Curitiba & $\begin{array}{c}\text { Primeiro } \\
\text { planalto }\end{array}$ & 0 & 0 & 1 & 0 \\
\hline Flávio Chichorro & Comerciante & Antonina & Litoral & 0 & 0 & 1 & 0 \\
\hline $\begin{array}{c}\text { Francisco } \\
\text { Martins Franco }\end{array}$ & Médico & Curitiba & $\begin{array}{l}\text { Primeiro } \\
\text { planalto }\end{array}$ & 0 & 0 & 0 & 1 \\
\hline $\begin{array}{c}\text { Francisco José } \\
\text { Guérios }\end{array}$ & Médico & Curitiba & $\begin{array}{l}\text { Primeiro } \\
\text { planalto }\end{array}$ & 0 & 0 & 0 & 1 \\
\hline $\begin{array}{c}\text { Gustavo Lessa de } \\
\text { Souza }\end{array}$ & Médico & Jacarezinho & $\begin{array}{l}\text { Terceiro } \\
\text { planalto }\end{array}$ & 1 & 2 & 0 & 0 \\
\hline $\begin{array}{c}\text { Jerônimo Cabral } \\
\text { Pereira do } \\
\text { Amaral }\end{array}$ & Advogado & Castro & $\begin{array}{l}\text { Segundo } \\
\text { planalto }\end{array}$ & 0 & 2 & 2 & 0 \\
\hline
\end{tabular}


conclusão

\begin{tabular}{|c|c|c|c|c|c|c|c|}
\hline Nome & Ocupação & $\begin{array}{l}\text { Município de } \\
\text { residência }\end{array}$ & $\begin{array}{l}\text { Região do } \\
\text { Estado do } \\
\text { Paraná }\end{array}$ & $\begin{array}{c}\text { Total de mandatos } \\
\text { no Poder Executivo } \\
\text { (Primeira República) }\end{array}$ & $\begin{array}{l}\text { Total de mandatos } \\
\text { no Poder Legislativo } \\
\text { (Primeira República) }\end{array}$ & $\begin{array}{l}\text { Total de nomeações } \\
\text { para cargos públicos } \\
\text { (Primeira República) }\end{array}$ & $\begin{array}{l}\text { Total de nomeações } \\
\text { para cargos públicos } \\
\text { (Governo Provisório) }\end{array}$ \\
\hline $\begin{array}{c}\text { *Joaquim Pereira } \\
\text { de Macedo }\end{array}$ & Industrial & Curitiba & $\begin{array}{l}\text { Primeiro } \\
\text { planalto }\end{array}$ & ( & 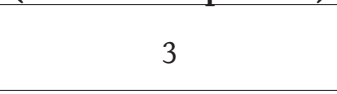 & 年 & 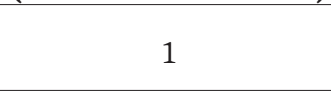 \\
\hline Joanino Sabatella & Dentista & Ponta Grossa & $\begin{array}{l}\text { Primeiro } \\
\text { planalto }\end{array}$ & 0 & 0 & 0 & 0 \\
\hline *Jorge Becher & Comerciante & Ponta Grossa & $\begin{array}{l}\text { Segundo } \\
\text { planalto }\end{array}$ & 0 & 1 & 0 & 2 \\
\hline $\begin{array}{c}\text { José Joaquim } \\
\text { Correia }\end{array}$ & Fazendeiro & Joaquim Távora & $\begin{array}{l}\text { Terceiro } \\
\text { planalto }\end{array}$ & 0 & 0 & 0 & 0 \\
\hline Lúcio Correia & Advogado & Ribeirão Claro & $\begin{array}{l}\text { Terceiro } \\
\text { planalto }\end{array}$ & 0 & 0 & 0 & 0 \\
\hline $\begin{array}{l}\text { *Manuel } \\
\text { de Alencar } \\
\text { Guimarães }\end{array}$ & Advogado & Curitiba & $\begin{array}{l}\text { Primeiro } \\
\text { planalto }\end{array}$ & 1 & 18 & 2 & 1 \\
\hline $\begin{array}{c}\text { Mário Monteiro } \\
\text { Tourinho }\end{array}$ & Militar & Curitiba & $\begin{array}{l}\text { Primeiro } \\
\text { planalto }\end{array}$ & 0 & 0 & 0 & 1 \\
\hline $\begin{array}{c}\text { Oscar Martins } \\
\text { Gomes }\end{array}$ & Advogado & Curitiba & $\begin{array}{l}\text { Primeiro } \\
\text { planalto }\end{array}$ & 0 & 0 & 0 & 1 \\
\hline Osvaldo Guizard & Farmacêutico & Cambará & $\begin{array}{l}\text { Terceiro } \\
\text { planalto }\end{array}$ & 1 & 0 & 0 & 0 \\
\hline Reinoldo Weigert & Ferroviário & Ponta Grossa & $\begin{array}{l}\text { Primeiro } \\
\text { planalto }\end{array}$ & 0 & 0 & 0 & 0 \\
\hline Roberto Barroso & Advogado & Paranaguá & Litoral & 0 & 0 & 1 & 0 \\
\hline Saturnino Luz & Advogado & Curitiba & $\begin{array}{l}\text { Primeiro } \\
\text { planalto }\end{array}$ & 0 & 0 & 0 & 0 \\
\hline $\begin{array}{c}\text { Ulisses Falcão } \\
\text { Vieira }\end{array}$ & Advogado & Curitiba & $\begin{array}{l}\text { Primeiro } \\
\text { planalto }\end{array}$ & 2 & 2 & 5 & 2 \\
\hline
\end{tabular}

Fontes: A República (PR); Diário da Tarde (PR); Diário do Comércio (PR); Gazeta do Povo (PR); O Dia (PR). 
A reorganização do quadro partidário não determinou o encerramento da atuação política de parentelas que haviam atuado nos partidos e nas esferas administrativas do Paraná da Primeira República. Ao contrário, há evidências de que tal reorganização consistiu em uma oportunidade para a inserção na cena política de indivíduos cujas parentelas, nos anos anteriores à Revolução de 1930, estavam afastadas das disputas eleitorais. ${ }^{44}$

Cabe salientar que esse evento não pôs fim à atividade política do ex-senador Manuel de Alencar Guimarães. Esse bacharel se enquadra na categoria dos veteranos que, por meio da adesão ao Governo Vargas, conquistaram cargos na administração pública. ${ }^{45}$ No início dos anos 1930 , antes de ser eleito deputado estadual pelo PSN, Alencar Guimarães conseguira ser absorvido pela ordem governista. Após a ascensão de Vargas à Presidência da República, ele participou de políticas de nomeações para órgãos públicos. No primeiro semestre de 1934, por exemplo, atuou como juiz do Tribunal Eleitoral do Paraná. ${ }^{46}$

O envolvimento em esquemas de nomeações consistiu no limite da relação de veteranos como Alencar Guimarães com o grupo governista constituído a partir de 1930. Tal envolvimento não levou Alencar Guimarães a ingressar no PSD, a agremiação governista do Paraná. Contudo, a passagem do ex-senador para a oposição não criou obstáculos para os seus familiares serem integrados a esferas da administração estadual. ${ }^{47}$

Em última análise, o PSN não foi apenas o refúgio para os apoiadores da Revolução de 1930 que se desligaram do governismo paranaense ao tempo da Primeira República. Essa grei também foi o espaço para a acomodação de

\footnotetext{
${ }^{44}$ No Quadro 2, nota-se a presença de Alceu do Amaral Ferreira. Ele era filho de João Cândido Ferreira (1864-1948), que foi governador do Paraná de 1906 a 1907 e membro do PSN. Nos anos 1930, a força eleitoral desses familiares não era equivalente. Contrariamente a seu filho, João Cândido não teve êxito nas eleições legislativas de 1934. Assim, cumpre evidenciar que o vínculo a uma parentela da elite política estadual não assegurou a todos os candidatos desse partido o sucesso em pleitos ocorridos nos anos 1930.

${ }^{45}$ Alencar Guimarães era proveniente de uma parentela que estava em atividade na política paranaense desde a época do Império. Nesse contexto, os membros dessa família pertenceram ao Partido Conservador. Ver ALVES, A Província do Paraná... op. cit. Durante as duas primeiras décadas republicanas, os Guimarães integraram o Partido Republicano do Paraná, de orientação governista. Em 1915, migraram para a oposição. Acerca dos movimentos de tal família na cena política, ver GOULART, Classe dominante... op. cit.

${ }^{46}$ Diário da Tarde, Curitiba, 26 jun. 1934, p. 1.

${ }^{47}$ Nessa época, havia membros da família Guimarães que viviam na cidade de Ponta Grossa, situada no segundo planalto do Paraná. Acerca da capacidade de essa parentela permanecer integrada a esferas locais da administração pública, cabe atentar às seguintes informações publicadas no Diário da Tarde agosto de em 1934: "Depois que o Sr. Flávio Guimarães passou a mandar na política do Estado, só dá Guimarães em todas as nomeações. Ainda hoje o Governo publicou decretos nomeando: prefeito de Ponta Grossa, o Sr. Albari Guimarães; Delegado de Polícia da 'Princesa' [Ponta Grossa], o Sr. Adolphito Guimarães." Diário da Tarde, Curitiba, 15 ago. 1934, p. 1.
} 
veteranos cuja adesão ao Governo Vargas não foi sucedida pela filiação ao partido situacionista do estado. ${ }^{48}$

A terceira constatação afirma que os dirigentes do PSN inseriram em sua chapa os representantes de distintos segmentos profissionais. Esses dirigentes ambicionaram angariar eleitores junto aos trabalhadores urbanos e estudantes. O ferroviário Reinoldo Weigert era identificado com os trabalhadores de modesta condição social. Álvaro Gonçalves de Quadros, então acadêmico do curso de Direito da Universidade do Paraná, fora incluído na lista de candidatos para amealhar o voto da classe estudantil. Na eleição de estadual de 1934, tal estratégia também foi adotada por outro partido de oposição, a URP. ${ }^{49}$

A despeito de terem malogrado, tais candidaturas são evidências de que os líderes de oposição reconheceram a pertinência de conquistarem adesões em diferentes camadas sociais. No entanto, o perfil predominante dos candidatos do PSN era semelhante ao perfil das elites políticas de distintos estados, a exemplo de São Paulo. Um dos elementos desse perfil era a posse de um diploma de curso superior. ${ }^{50}$ Outro elemento era a inclinação para o desenvolvimento de uma carreira em instituições políticas estaduais. ${ }^{51}$

\section{O perfil dos candidatos à Câmara dos Deputados pelo PSN: aspectos de suas origens sociais e percursos políticos}

O estudo sobre a composição da chapa de candidatos do PSN para o cargo de deputado federal permite salientar as características e limites da renovação do quadro partidário estadual. Tal estudo também favorece o reconhecimento de distinções entre os políticos veteranos e novatos que se

\footnotetext{
${ }^{48}$ Ao tempo da ascensão de Getúlio Vargas à Presidência da República, Alencar Guimarães encontrava-se no exercício do cargo de Inspetor Consular para a América do Sul e Sul da África. Ele obteve tal posto em 1927, por meio de nomeação do presidente Washington Luís. Uma das medidas tomadas pelo Governo Vargas em fins de 1930 foi extinguir esse cargo. 0 Dia, Curitiba, 18 dez. 1930, p. 8. Portanto, os primeiros efeitos da ascensão de Vargas à Presidência da República foram desfavoráveis a Alencar Guimarães. Todavia, os membros de sua parentela começaram a se reintegrar nas esferas administrativas no ano seguinte àquele movimento político. Em 1931, João de Alencar Guimarães, irmão do ex-senador, exerceu o posto de Inspetor de Veículos do Estado do Paraná. Foi gradual a reinserção dessa parentela às agências do Estado. O Dia, Curitiba, 1 abr. 1931, p. 2.

${ }^{49} \mathrm{~A}$ URP lançou o ferroviário Eugênio Ricetti e o estudante de Direito Elias Karam como candidatos à Assembleia do Paraná. No entanto, eles não conseguiram se eleger. Diário da Tarde, Curitiba, 28 set. 1934, p. 2.

${ }^{50}$ Acerca dos elementos típicos aos perfis sociais de integrantes das elites regionais no contexto dos primeiros anos da década de 1930, ver COSTA; MASSIMO; PERISSINOTTO, Oligarquia Competitiva e Profissionalização Política... op. cit.

${ }^{51}$ Ver LOVE, Joseph. A Locomotiva: São Paulo na federação (1889-1937). Rio de Janeiro: Paz e Terra, 1982.
} 
filiaram ao PSN. Um aspecto central dessas distinções era quanto à sua força eleitoral. Atente-se, pois, às informações do Quadro 3.

Quadro 3: Atuação política e profissional dos candidatos do Partido Social Nacionalista a deputado federal pelo Paraná (1934) ${ }^{52}$

\begin{tabular}{|c|c|c|c|c|c|c|c|}
\hline Nome & Ocupação & $\begin{array}{l}\text { Município } \\
\text { de } \\
\text { residência }\end{array}$ & $\begin{array}{l}\text { Região } \\
\text { do } \\
\text { Estado } \\
\text { do } \\
\text { Paraná }\end{array}$ & $\begin{array}{c}\text { Total de } \\
\text { mandatos } \\
\text { no Poder } \\
\text { Executivo } \\
\text { (Primeira } \\
\text { República) }\end{array}$ & $\begin{array}{c}\text { Total de } \\
\text { mandatos } \\
\text { no Poder } \\
\text { Legislativo } \\
\text { (Primeira } \\
\text { República) }\end{array}$ & $\begin{array}{c}\text { Total de } \\
\text { nomeações } \\
\text { para } \\
\text { cargos } \\
\text { públicos } \\
\text { (Primeira } \\
\text { República) }\end{array}$ & $\begin{array}{c}\text { Total de } \\
\text { nomeações } \\
\text { para } \\
\text { cargos } \\
\text { públicos } \\
\text { (Governo } \\
\text { Provisório) }\end{array}$ \\
\hline $\begin{array}{c}\text { Catão } \\
\text { Menna } \\
\text { Barreto } \\
\text { Monclaro }\end{array}$ & Militar & Curitiba & $\begin{array}{l}\text { Primeiro } \\
\text { planalto }\end{array}$ & 0 & 0 & 0 & 1 \\
\hline $\begin{array}{c}\text { João } \\
\text { Cândido } \\
\text { Ferreira }\end{array}$ & Médico & Curitiba & $\begin{array}{c}\text { Primeiro } \\
\text { planalto }\end{array}$ & 3 & 3 & 0 & 0 \\
\hline $\begin{array}{c}\text { José } \\
\text { Pereira de } \\
\text { Macedo }\end{array}$ & Médico & Curitiba & $\begin{array}{c}\text { Primeiro } \\
\text { planalto }\end{array}$ & 0 & 0 & 1 & 1 \\
\hline $\begin{array}{c}\text { Marcelino } \\
\text { Nogueira } \\
\text { Júnior }\end{array}$ & Advogado & Lapa & $\begin{array}{l}\text { Primeiro } \\
\text { planalto }\end{array}$ & 0 & 4 & 2 & 0 \\
\hline $\begin{array}{c}\text { *Plínio } \\
\text { Monteiro } \\
\text { Tourinho }\end{array}$ & Militar & Curitiba & $\begin{array}{l}\text { Primeiro } \\
\text { planalto }\end{array}$ & 0 & 0 & 0 & 2 \\
\hline $\begin{array}{l}\text { Roberto } \\
\text { Glasser }\end{array}$ & Agropecuarista & Curitiba & $\begin{array}{c}\text { Primeiro } \\
\text { planalto }\end{array}$ & 0 & 1 & 0 & 1 \\
\hline
\end{tabular}

Fontes: A República (PR); Diário da Tarde (PR); Diário do Comércio (PR); Gazeta do Povo (PR); O Dia (PR).

A análise das informações contidas nesse Quadro possibilita a sustentação de duas afirmações. Primeiro, nota-se que os políticos veteranos, oriundos dos partidos estaduais da Primeira República, não conseguiram se eleger. 0 candidato mais competitivo dessa chapa era um militar desprovido de longa experiência nas lides partidárias. Em última instância, os veteranos

${ }^{52} \mathrm{O}$ indivíduo cujo nome é precedido por um asterisco foi eleito deputado federal em 1934. 
conquistaram um espaço no núcleo dirigente e nas chapas de candidatos do PSN. Porém, eles não possuíam análogo desempenho eleitoral.

Os veteranos menos competitivos eram aqueles que, após algumas passagens pelos partidos governistas da Primeira República, não assumiram funções relevantes nas agremiações e nas campanhas eleitorais da oposição. Ou seja, trata-se de um conjunto de políticos cuja atuação na vida partidária fora interrompida no fim dos anos 1900. Este era o caso do ex-governador João Cândido Ferreira, bem como do ex-deputado estadual Marcelino Nogueira Júnior..$^{53}$

Por outro lado, o envolvimento contínuo em campanhas políticas ao tempo da Primeira República e do Governo Provisório foi um fator que conferiu maior competividade a uma parcela dos veteranos filiados ao PSN. Conforme acima destacado, tal situação foi peculiar aos casos de Joaquim Macedo e Manuel de Alencar Guimarães. Ela também foi inerente ao caso de Roberto Glasser. ${ }^{54}$

A segunda constatação salienta que os dirigentes do PSN conferiram a políticos novatos a oportunidade de disputarem o cargo de deputado federal. Assim, metade dos integrantes da chapa era formada por indivíduos que não haviam participado de eleições anteriormente a 1930.

A composição da chapa de postulantes à Câmara Federal pelo PSN evidencia que existiam precisos critérios para a concessão de oportunidades a esses novatos. Um critério era a participação na campanha eleitoral conduzida pela Aliança Liberal, em 1930. Os escolhidos para formar a chapa estavam politicamente articulados desde a época anterior à criação do PSN. Os militares incluídos na chapa faziam parte de tal categoria de novatos. ${ }^{55}$ Outro critério

\footnotetext{
${ }^{53}$ Quando se candidatou a deputado federal, em 1934, Marcelino Nogueira estava sem exercer mandato eletivo havia vinte e cinco anos. Ele não pertenceu aos partidos de oposição criados no Paraná a partir dos anos 1910. Em verdade, nos primeiros anos do Governo Provisório ele não estava integrado a um partido. Nesse contexto, concentrou-se em atuar como advogado e em participar da gestão da seção paranaense da Ordem dos Advogados do Brasil. Diário da Tarde, Curitiba, 16 fev. 1932, p. 4. Na época em que se candidatou a deputado federal pelo PSN, João Cândido Ferreira estava sem desempenhar um mandato havia vinte e sete anos. Após deixar o cargo de governador do Paraná, em 1907, ele não manteve vínculo formal com um partido. Nos meses anteriores à queda do presidente Washington Luís, Ferreira se dedicava às atividades de médico e professor universitário. Diário da Tarde, Curitiba, 9 jun. 1930, p. 1. Em suma, Ferreira e Nogueira pertenciam a uma categoria de veteranos cuja atividade partidária foi retomada no biênio 1933-1934, época da reorganização do quadro partidário do estado.

${ }^{54}$ De fato, Roberto Glasser não conseguiu se eleger deputado federal em 1934. No entanto, ele alcançou a condição de primeiro suplente. Ou seja, Glasser foi o mais votado dentre os políticos veteranos da sua chapa. O Dia, Curitiba, 26 out. 1934, p. 1.

${ }^{55}$ Catão Menna Barreto e Plínio Tourinho fizeram parte do grupo dos militares que apoiaram a Aliança Liberal e não reconheceram a derrota de Getúlio Vargas à Presidência da República. A esse respeito, ver FRANCO, André Luiz dos Santos. As armas de outubro: militares e políticos no movimento belicista de 1930
} 
para a seleção de novatos era o vínculo a uma parentela dotada de longo envolvimento nas lides políticas. José Pereira de Macedo, filho do presidente do partido, pertenceu a esse grupo de estreantes.

\section{As chapas concorrentes nas eleições parlamentares de 1934: aspectos dos perfis políticos de seus integrantes}

O estudo realizado nesta seção permite reconhecer analogias quanto à forma de confecção das chapas de candidatos pelos partidos dominantes então existentes no Paraná. De um lado, cumpre demonstrar a afirmação segundo a qual tais partidos se assemelharam em virtude do amplo espaço que concederam a políticos novatos em suas chapas. De outro lado, trata-se de evidenciar os desníveis entre tais agremiações quanto ao seu desempenho eleitoral. Para tanto, cabe dedicar atenção ao contexto político em que as eleições de 1934 foram realizadas.

No mencionado ano, no Paraná, o PSD, o PSN e a URP eram os partidos mais competitivos. Dentre tais agremiações, o PSD possuía o maior número de mandatários. ${ }^{56}$ Contudo, havia outros grupos políticos organizados no estado. Um desses grupos era a Ação Integralista Brasileira (AIB). Ela possuía adeptos em diferentes cidades. Mais precisamente, estava em curso um processo de expansão das unidades locais dessa grei. No entanto, o limite da força eleitoral da AIB consistiu em eleger vereadores na capital e em municípios do interior. ${ }^{57}$

De outra parte, havia setores do operariado politicamente articulados. Essa articulação resultou na criação, em 1933, do Partido Reivindicador Proletário do Paraná (PRPP). Nesse estado, a inclinação de trabalhadores urbanos para atuarem nas lides políticas data da época da Primeira República. ${ }^{58}$ No começo dos anos 1930, o surgimento do PRPP representou a principal iniciativa voltada ao lançamento candidaturas de membros do movimento operário..$^{59}$ Entretanto, agremiações como a AIB e o PRPP não possuíam a

no sul do Brasil. Dissertação (Mestrado em História). Universidade Federal do Paraná. Curitiba, 2010.

${ }^{56}$ Diário da Tarde, 27 set. 1937, p. 2.

${ }^{57}$ Acerca da implantação de unidades da Ação Integralista Brasileira em cidades paranaenses, ver DITZEL, Carmencita de Holleben Mello. Imaginários e representações: o Integralismo nos Campos Gerais. Ponta Grossa: Ed. da UEPG, 2007; OLIVEIRA, Luiz Gustavo de. Devotos do Sigma: integralistas de Teixeira Soares/PR, 19351938. Dissertação (Mestrado em História). Universidade Estadual do Centro-Oeste do Paraná. Irati, 2015.

${ }^{58}$ Ver ARAÚJO, Sílvia; CARDOSO, Alcinda (Org.). Jornalismo e militância operária. Curitiba: Ed. da UFPR, 1992.

${ }^{59}$ Ver MONTEIRO, Cláudia. Ferroviários em greve: relações de dominação e resistência na RVPSC. Revista de História Regional. Ponta Grossa, v. 12, n. 1, 2007, p. 9-24. Em verdade, no contexto das eleições parlamentares de 1934 o PRPP já passara por uma cisão. Os dissidentes de tal partido migraram para uma agremiação denominada Concentração Trabalhista. O Dia, Curitiba, 12 set. 1934, p. 1. 
força eleitoral necessária para suplantar as candidaturas chanceladas pelos partidos dominantes. ${ }^{60}$

Em relação à Primeira República, o cenário partidário que vigorou no Paraná dos anos 1930 era mais plural. Essa pluralidade decorria do fato de que estavam em atividade partidos estaduais, bem como havia coligações que se formaram com a finalidade de participar de apenas um pleito eleitoral. Tal situação era semelhante àquela verificada nos demais estados. Assim, tanto políticos destituídos em 1930 quanto novatos da cena partidária se ocuparam da tarefa de fundar agremiações regionais. ${ }^{61}$

Cabe destacar que as cisões internas à oposição paranaense foram responsáveis por tornar mais diversificado o cenário partidário. Um dos motivos da formação das coligações eleitorais no Paraná eram as dissidências nos partidos. ${ }^{62} \mathrm{O}$ outro motivo era a tentativa de sustentar um preciso repertório de propostas..$^{63}$ De todo modo, na mencionada disputa foram apenas os candidatos do PSD, PSN e URP que conseguiram se eleger para cargos parlamentares.

Em suma, a peculiaridade do pleito ocorrido no Paraná em 1934 reside no fato de que não houve tentativas de aliança entre os setores da oposição. Em Minas Gerais e São Paulo, havia maior coesão entre os adversários do Governo Vargas. Em ambos os estados, os partidos que reuniam os políticos destituídos pela Revolução de 1930 não foram eleitoralmente ameaçados por agremiações minoritárias. ${ }^{64}$

\footnotetext{
${ }^{60} \mathrm{Em}$ ordem decrescente, os grupos políticos mais votados no Paraná foram os seguintes: (1) Partido Social Democrático; (2) União Republicana Paranaense; (3) Partido Social Nacionalista; (4) Coligação Pró-Estado Leigo; (5) Coluna de Consolidação Cívica e Econômica; (6) Ação Integralista Brasileira; (7) Concentração Trabalhista; (8) Partido Reivindicador Proletário Paranaense; (9) Universitário Independente. Gazeta do Povo, Curitiba, 2 nov. 1934, p. 1. Os três primeiros partidos foram os únicos que conseguiram eleger seus candidatos no pleito estadual de 1934.

${ }^{61}$ A relação dos partidos estaduais que existiram nos estados brasileiros de 1933 a 1934 está contida em RICCI, Paolo (Org.). O autoritarismo eleitoral dos anos trinta e o Código Eleitoral de 1932. Curitiba: Appris, 2019, p. 281-283.

${ }^{62}$ Conforme acima ressaltado, o surgimento da Concentração Trabalhista decorreu de uma dissidência partidária. A Coluna Cívica, por seu turno, foi organizada pela Associação Comercial do Paraná (ACP). Diário da Tarde, Curitiba, 25 set. 1934, p. 1. Ao promover o lançamento de candidaturas, a ACP buscou reabilitar uma prática que adotara ao tempo da Primeira República. Tal prática consistia em apoiar candidatos independentes em eleições parlamentares. Diário da Tarde, Curitiba, 30 ago. 1915, p. 1.

${ }^{63} \mathrm{Em}$ tal categoria se enquadra a Coligação Pró-Estado Leigo, que defendia a restauração "do Estado Leigo em sua plenitude no Brasil; adoção do divórcio e emancipação completa da mulher". Diário da Tarde, Curitiba, 15 ago. 1934, p. 1. Após o pleito, contudo, os membros dessa Coligação aliaram-se a setores do PSD e do PSN. Ou seja, elas não desenvolveram uma atividade política autônoma por longo tempo. Diário da Tarde, Curitiba, 28 mai. 1935, p. 5.

${ }^{64}$ Em São Paulo, o Partido Republicano Paulista (PRP) foi o principal representante da oposição, após a dissolução do Partido Democrático. Em Minas Gerais, o Partido Republicano Mineiro (PRM) liderou a oposição. O PRP e o PRM conseguiram preencher pouco mais de um terço das vagas de deputado estadual
} 
A falta de unidade entre os oposicionistas do Paraná não criou obstáculos para que os adversários dos situacionistas conquistassem algumas cadeiras na Assembleia Legislativa e na Câmara dos Deputados. Ao contrário, no pleito de 1934 ocorreu uma situação já observada nas eleições de 1933. Tal situação consistiu na eleição de oposicionistas sem a necessidade de o partido situacionista apresentar chapas incompletas. Em tal época, portanto, houve o crescimento da força eleitoral dos grupos de oposição ao Governo do Estado.

$* * *$

Cumpre, por conseguinte, analisar a composição das chapas de candidatos a deputado estadual pelos partidos mais competitivos do Paraná. Tal análise requer, preliminarmente, a atenção às informações presentes no Quadro 4.

Quadro 4: Composição das chapas de candidatos a deputado estadual pelos partidos predominantes do Paraná (1934)

\begin{tabular}{|c|c|c|c|c|c|}
\hline Partido & $\begin{array}{c}\text { Número de } \\
\text { candidatos }\end{array}$ & $\begin{array}{c}\text { Total } \\
\text { de } \\
\text { eleitos } \\
\text { ocupantes } \\
\text { de mandatos } \\
\text { eletivos na } \\
\text { Primeira } \\
\text { República }\end{array}$ & $\begin{array}{c}\text { Total de } \\
\text { ocupantes } \\
\text { de cargos } \\
\text { comissionados } \\
\text { na Primeira } \\
\text { República }\end{array}$ & $\begin{array}{c}\text { Total de } \\
\text { ocupantes } \\
\text { de cargos } \\
\text { comissionados } \\
\text { no Governo } \\
\text { Provisório }\end{array}$ \\
\hline $\begin{array}{c}\text { Partido Social } \\
\text { Democrático }\end{array}$ & 30 & 20 & 3 & 7 & 9 \\
\hline $\begin{array}{c}\text { Partido Social } \\
\text { Nacionalista }\end{array}$ & 30 & 5 & 9 & 10 & 10 \\
\hline $\begin{array}{c}\text { União } \\
\text { Republicana } \\
\text { Paranaense }\end{array}$ & 30 & 5 & 9 & 12 & 1 \\
\hline
\end{tabular}

Fontes: A República (PR); Diário da Tarde (PR); Diário do Comércio (PR); Gazeta do Povo (PR); O Dia (PR).

As informações contidas nesse Quadro propiciam a sustentação de duas constatações. Primeiro, cumpre mencionar que a maior parte dos candidatos lançados pelos partidos dominantes ao cargo de deputado estadual era formada por indivíduos que não desempenharam mandatos durante a Primeira República. Os chefes partidários do Paraná destinaram um espaço expressivo para novos personagens da cena política.

e deputado federal nas eleições de 1934. Contrariamente ao caso do Paraná, nos referidos estados havia maior desnível quanto ao desempenho eleitoral das forças oposicionistas. Acerca do desempenho eleitoral de tais partidos, ver ABREU, Dicionário histórico-biográfico... op. cit. 
Nesse particular, cabe reconhecer que a URP não funcionou apenas como o refúgio para que políticos destituídos de seus mandatos pela Revolução de 1930 pudessem recuperar um espaço na cena partidária do Paraná. Os novatos que pertenceram a essa agremiação garantiram ao partido uma representação mínima na Assembleia Legislativa.

Convém ressaltar que, dos cinco deputados estaduais eleitos pela URP, dois eram estreantes em disputas eleitorais. No PSN, a votação angariada pelos novatos também propiciou a formação de uma bancada oposicionista naquela instituição. Assim, dos cinco deputados que o partido conseguiu eleger nessa ocasião, três eram novatos. O número de políticos novatos que se elegeram pelo PSD também era significativo. No rol dos vinte deputados estaduais que essa agremiação elegeu em 1934, dezessete ainda não haviam exercido mandatos no contexto da Primeira República. ${ }^{65}$

A segunda constatação afirma que, de 1933 a 1934, houve uma mudança no grau de competividade eleitoral dos partidos predominantes do Paraná. Notou-se, pois, um ligeiro predomínio da URP no que concerne ao total de sufrágios que obteve. Algumas lideranças partidárias identificadas com a ordem governista da Primeira República tiveram sucesso na tarefa de recuperar, em alguma medida, uma projeção no jogo político local.

A votação dos partidos predominantes na disputa pelas trinta vagas de deputado estadual foi a seguinte: PSD: 22.441; URP: 8.964; PSN: $8.416 .{ }^{66}$ Tal resultado evidenciou o declínio da força eleitoral dos remanescentes do extinto PLP. Nessa ocasião, portanto, a URP começava a se consolidar como a principal grei oposicionista. Essa consolidação se completou com a mencionada fusão entre o PSD e o PSN.

O fato de o PSN e a URP terem elegido ao todo dez candidatos corrobora a afirmação de que, na época do Governo Provisório, houve a elevação da força eleitoral dos partidos da oposição paranaense. Analogamente à situação verificada em 1933, tais agremiações ambicionaram conquistar todas as vagas abertas nas eleições parlamentares de 1934.

Esse pleito ocorreu no contexto em que os partidos predominantes do Paraná apresentaram chapas completas. Tal apresentação significou um rompimento com a prática, adotada pelas agremiações oposicionistas, de lançar um número de candidaturas menor do que o total de vagas em disputa. 0 lançamento de chapas incompletas foi uma iniciativa recorrente das oposições

${ }^{65}$ O Dia, Curitiba, 30 out. 1934 , p. 1.

${ }^{66}$ Gazeta do Povo, Curitiba, 2 nov. 1934, p. 1. 
estaduais durante a Primeira República. ${ }^{67} \mathrm{Em} 1934$, pela primeira vez na história eleitoral do Paraná, os oposicionistas conseguiram impedir o domínio de uma agremiação governista sobre todas as cadeiras da Assembleia Legislativa.

De outra parte, cabe mencionar que havia aproximações quanto aos critérios da composição das chapas de deputado estadual e deputado federal pelos partidos predominantes do estado. Para a corroboração dessa afirmação, cumpre analisar as informações inseridas no Quadro 5.

Quadro 5: Composição das chapas de candidatos a deputado federal pelos partidos predominantes do Paraná (1934)

\begin{tabular}{|c|c|c|c|c|c|}
\hline Partido & $\begin{array}{c}\text { Número de } \\
\text { candidatos }\end{array}$ & $\begin{array}{c}\text { Total de } \\
\text { eleitos }\end{array}$ & $\begin{array}{c}\text { Total de } \\
\text { ocupantes } \\
\text { de mandatos } \\
\text { eletivos na } \\
\text { Primeira } \\
\text { República }\end{array}$ & $\begin{array}{c}\text { Total de } \\
\text { ocupantes } \\
\text { de cargos } \\
\text { comissionados } \\
\text { na Primeira } \\
\text { República }\end{array}$ & $\begin{array}{c}\text { Total de } \\
\text { ocupantes } \\
\text { de cargos } \\
\text { comissionados } \\
\text { no Governo } \\
\text { Provisório }\end{array}$ \\
\hline $\begin{array}{c}\text { Partido Social } \\
\text { Democrático }\end{array}$ & 6 & 4 & 0 & 1 & 4 \\
\hline $\begin{array}{c}\text { Partido Social } \\
\text { Nacionalista }\end{array}$ & 6 & 1 & 3 & 2 & 4 \\
\hline $\begin{array}{c}\text { União } \\
\text { Republicana } \\
\text { Paranaense }\end{array}$ & 6 & 1 & 1 & 4 & 0 \\
\hline
\end{tabular}

Fontes: A República (PR); Diário da Tarde (PR); Diário do Comércio (PR); Gazeta do Povo (PR); O Dia (PR).

Em 1934, a votação dos partidos predominantes do Paraná na disputa pelas seis vagas de deputado federal foi a seguinte: PSD: 13.786; URP: 8.943; PSN: $8.621 .^{68} \mathrm{~A}$ principal semelhança existente entre as chapas compostas pelos partidos predominantes dizia respeito à inclusão de candidatos sem experiência prévia no exercício de mandatos. Os novatos incluídos nas chapas oposicionistas eram eleitoralmente mais fortes do que os veteranos que pleitearam uma vaga na Câmara dos Deputados.

Trata-se de mencionar que os dois candidatos de oposição que se elegeram deputados federais em 1934 (Artur Santos, da URP, e Plínio Tourinho, do

\footnotetext{
${ }^{67}$ Respeitante às estratégias eleitorais adotadas pelas oposições estaduais entre as décadas de 1890 a 1920, ver FIGUEIREDO, Vítor Fonseca. Voto e competição política na Primeira República: o caso de Minas Gerais. Tese (Doutorado em História). Universidade Federal de Juiz de Fora. Juiz de Fora, 2016.

${ }^{68}$ Gazeta do Povo, Curitiba, 2 nov. 1934, p. 1.
} 
PSN) não haviam disputado eleições na época anterior ao Governo Provisório. No Paraná, o início da Era Vargas foi marcado pela redução das bases eleitorais de indivíduos que começaram a atuar na vida política ao tempo da Primeira República.

A esse respeito, atente-se ao caso do ex-senador Marins Alves de Camargo (1882-1962). Ele foi o responsável por reorganizar o grupo de políticos paranaenses destituídos de seus cargos pela Revolução de $1930 .{ }^{69}$ Ao tempo das eleições parlamentares de 1934, Camargo tinha uma posição de protagonismo no cenário partidário regional. Porém, a conquista da legitimidade de exercer um controle sobre os diretórios da URP não foi acompanhada pela recuperação da força eleitoral que tivera na época da Primeira República. Na referida disputa, Camargo não conseguiu se eleger deputado federal. ${ }^{70}$

No PSN, há o caso da candidatura do citado João Cândido Ferreira, que também não teve êxito nesse pleito. O seu partido não o escolheu como cabeça de chapa, isto é, o postulante que disputava o primeiro turno da eleição com os líderes das outras chapas. Ele foi incluído como candidato da disputa em segundo turno. ${ }^{71} \mathrm{Na}$ época da criação do PSN, uma parcela dos veteranos estava em uma posição mais periférica em relação aos novatos tanto na direção da grei quanto no interior das chapas.

Por fim, trata-se de salientar que as chapas que o PSN apresentou para o cargo de deputado federal contavam com a participação de membros de parentelas que, havia décadas, estavam em atividade na vida política do Paraná. Tais parentelas não se limitaram a conquistar posições centrais naquela agremiação. Elas também ambicionaram retornar às instituições políticas estaduais.

A vinculação a essas parentelas não proporcionava, em todos os casos, uma vitória eleitoral. A esse respeito, cabe mencionar que um dos candidatos lançados pelo PSN à Câmara dos Deputados era o citado José Pereira de Macedo. Ao passo que o pai desse médico conseguiu se eleger deputado estadual em 1934, o seu filho malogrou no propósito de obter uma vaga de deputado federal. Assim, não era equânime a força eleitoral dos indivíduos que, acomodados no PSN, pertenciam a famílias marcadas pelo longo pertencimento ao quadro partidário paranaense.

Por fim, cumpre salientar que em 1935 o PSN apresentou candidatos a vereador em distintos municípios. 0 partido conseguiu eleger alguns de seus

\footnotetext{
${ }^{69}$ O Dia, Curitiba, 9 jan. 1933, p. 1.

${ }^{70}$ Gazeta do Povo, Curitiba, 2 nov. 1934, p. 1.

${ }^{71}$ Diário da Tarde, Curitiba, 19 set. 1934, p. 1.
} 
candidatos. Porém, nessa disputa o PSN não ameaçou o predomínio eleitoral do PSD. Em tal época, em cidades como Curitiba, o PSN era eleitoralmente menos competitivo do que a AIB. Nesse município, os integralistas elegeram três vereadores. O PSN elegeu apenas dois. O PSD elegeu sete candidatos. ${ }^{72}$ Tais informações permitem corroborar a constatação de que, após as eleições estaduais de 1934, o PSN não se consolidou como o principal adversário do partido situacionista. Ao tempo da fusão com o PSD, os membros do PSN não exerciam a liderança do campo oposicionista no Paraná. ${ }^{73}$

\section{Considerações finais}

A análise desenvolvida neste artigo teve por objetivo avançar no conhecimento sobre a organização interna e a força eleitoral dos partidos de oposição surgidos nos anos seguintes à Revolução de 1930. O estudo do caso do PSN, uma agremiação oposicionista que existiu no Paraná de 1934 a 1937, permitiu a sustentação de três afirmações.

Primeiro, cumpre salientar que essa agremiação não foi apenas um refúgio para políticos veteranos tentarem se reabilitar na vida política. Ela não foi comandada somente por indivíduos provenientes dos partidos estaduais da Primeira República. O PSN foi o espaço para o aparecimento de uma nova geração de políticos.

Os novatos eram a maioria na chapa de candidatos à Assembleia do Paraná apresentada pelo PSN no pleito de 1934. Eles também preencheram metade das vagas na chapa de candidatos a deputado federal lançada por esse partido. Uma parcela desses novatos se mostrou eleitoralmente mais forte do que os indivíduos que possuíam maior experiência na vida partidária. 0 bom desempenho de candidatos novatos do PSN nos pleitos para deputado federal e deputado estadual evidencia que o quadro político estadual experimentou uma renovação no início dos anos 1930.

Segundo, cumpre salientar que os políticos veteranos não foram proscritos do PSN. Essa agremiação incorporou aos seus quadros indivíduos que começaram a atuar na vida política ao tempo da Primeira República. O PSN foi um partido por meio do qual uma parcela dos veteranos pôde recuperar um espaço no jogo eleitoral do estado. Os correligionários provenientes de

\footnotetext{
${ }^{72}$ O Dia, Curitiba, 20 set. 1935 , p. 8.

${ }^{73}$ No Paraná, a AIB se enquadrava na condição de um partido de oposição. Ela era combatida pelo governador Manuel Ribas. A esse respeito, ver BERTONHA, João Fábio. Sombras autoritárias e totalitárias no Brasil: integralismo, fascismos e repressão política. Maringá: Ed. da UEM, 2013.
} 
parentelas da elite social paranaense encontraram no PSN o respaldo para se reintegrarem a uma cena política que experimentava mudanças desde o ano de 1930.

Terceiro, cumpre mencionar que a criação do PSN foi derivada da dificuldade de os oposicionistas paranaenses desenvolverem uma ação política conjunta. Tal dificuldade instaurou um cenário de acirrada competição entre os adversários do governismo. Nesse contexto, o PSN não se conservou na posição de principal força eleitoral da oposição. A desunião entre os contendores do situacionismo estadual foi um aspecto da vida política paranaense nos anos 1930. A falta de unidade ocasionou a passagem do PSN para o campo situacionista. A fusão desse partido com o PSD fortaleceu o grupo político que apoiava o governador Manuel Ribas.

\section{Referências bibliográficas}

ABREU, Alzira Alves de (Coord.). Dicionário histórico-biográfico da Primeira República (1889-1930). Rio de Janeiro: Ed. FGV, 2015.

ACHIAMÉ, Fernando. O Espírito Santo na Era Vargas (1930-1937). Rio de Janeiro: Ed. da FGV, 2010.

ALVES, Alessandro Cavassin. A Província do Paraná (1853-1889): a classe política, a parentela no Governo. Tese (Doutorado em Sociologia). Universidade Federal do Paraná. Curitiba, 2014.

ARAÚJO, Sílvia; CARDOSO, Alcinda (Org.). Jornalismo e militância operária. Curitiba: Ed. da UFPR, 1992.

BERTONHA, João Fábio. Sombras autoritárias e totalitárias no Brasil: integralismo, fascismos e repressão política. Maringá: Ed. da UEM, 2013.

CHARLE, Christophe. A prosopografia ou biografias coletivas: balanço e perspectivas. In: HEINZ, Flávio (Org.). Por outra história das elites. Rio de Janeiro: Ed. FGV, 2006, p. 41-54.

CODATO, Adriano Nervo. Elites e instituições: uma análise contextual do Estado Novo. Tese (Doutorado em Ciência Política). Universidade Estadual de Campinas. Campinas, 2008.

COSTA, Luiz Domingos; MASSIMO, Lucas; PERISSINOTTO, Renato Monseff. Oligarquia Competitiva e Profissionalização Política: o caso dos senadores 
brasileiros na Primeira República (1889-1934). Dados, Rio de Janeiro, v. 60, n. 1 , 2017, p. 79-110.

DAGOSTIM, Maristela Wessler. A República dos Conselhos: um estudo sobre a transformação do perfil da elite política paranaense (1930-1947). Dissertação (Mestrado em Ciência Política). Universidade Federal do Paraná. Curitiba, 2011.

DITZEL, Carmencita de Holleben Mello. Imaginários e representações: o Integralismo nos Campos Gerais. Ponta Grossa: Ed. da UEPG, 2007.

FIGUEIREDO, Vítor Fonseca. Voto e competição política na Primeira República: o caso de Minas Gerais. Tese (Doutorado em História). Universidade Federal de Juiz de Fora. Juiz de Fora, 2016.

FRANCO, André Luiz dos Santos. As armas de outubro: militares e políticos no movimento belicista de 1930 no sul do Brasil. Dissertação (Mestrado em História). Universidade Federal do Paraná. Curitiba, 2010.

GOULART, Mônica Helena Harrich Silva. Classe dominante e jogo político na Assembleia Legislativa Paranaense (1889-1930). Tese (Doutorado em Sociologia). Universidade Federal do Paraná. Curitiba, 2008.

GRANATO, Natália Cristina. O Poder Legislativo Paranaense no contexto da Revolução de 1930: um estudo dos capitais familiares e políticos dos deputados federais e estaduais (1930-1937). Revista do Núcleo de Estudos Paranaenses. Curitiba, v. 1, n. 5, p. 1-39, 2019.

LAPUENTE, Rafael Saraiva. A luta pelo poder: a política gaúcha em perspectiva (19341937). Dissertação (Mestrado em História). Pontifícia Universidade Católica do Rio Grande do Sul. Porto Alegre, 2016.

LEVINE, Robert M. O Regime de Vargas: os anos críticos (1934-1938). Rio de Janeiro: Nova Fronteira, 1980.

LOVE, Joseph. A Locomotiva: São Paulo na federação (1889-1937). Rio de Janeiro: Paz e Terra, 1982.

MARIZ, Marlene da Silva. A Revolução de 30 no Rio Grande do Norte. Brasília: Ed. Senado Federal, 1984.

MOURELLE, Thiago Cavaliere. Guerra pelo poder: a Câmara dos Deputados confronta Vargas (1934-1935). Tese (Doutorado em História). Universidade Federal Fluminense. Niterói, 2015. 
NEGRÃO, Francisco. Genealogia paranaense. V. 2. Curitiba: Imprensa Oficial do Paraná, 2004.

NICOLAU, Jairo. As eleições no Brasil: do Império aos dias atuais. Rio de Janeiro: Jorge Zahar, 2012.

NOHLEN, Dieter. Elections in the Americas: a Data Handbook. Vol. 2. Oxford: Oxford University Press, 2005.

NOLL, Maria Izabel; TRINDADE, Helgio (Org.). Estatísticas eleitorais do Rio Grande da América do Sul: 1823-2002. Porto Alegre: Ed. da UFRGS, 2004.

OLIVEIRA, Luiz Gustavo de. Devotos do Sigma: integralistas de Teixeira Soares/PR, 1935-1938. Dissertação (Mestrado em História). Universidade Estadual do CentroOeste do Paraná. Irati, 2015.

OLIVEIRA, Ricardo Costa de (Org.). A construção do Paraná moderno: políticos e política no Governo do Paraná de 1930 a 1980. Curitiba: Ed. da Secretaria de Estado de Ciência e Tecnologia, 2004.

_. Nota sobre a política paranaense de 1930 a 1945. Revista de Sociologia e Política. Curitiba, v. 1, n. 9, p. 47-56, 1997.

PANDOLFI, Dulce Chaves. A trajetória do Norte: uma tentativa de ascenso político. In: GOMES, Ângela Maria de Castro (Coord.). Regionalismo e centralização política: partidos e Constituinte nos anos 30. Rio de Janeiro: Nova Fronteira, 1980, p. 339-425.

PILOTO, Valfrido. Quando o Paraná se levantou como uma nação. Curitiba: Instituto Histórico, Geográfico e Etnográfico Paranaense, 1982.

PORTO, Walter Costa. 0 voto no Brasil: da Colônia à $6^{a}$ República. Rio de Janeiro: Topbooks, 2002.

PRADO, Maria Lígia Coelho. A democracia ilustrada: o Partido Democrático de São Paulo, 1926-1934. São Paulo: Ática, 1986.

RAMOS, Plínio de Abreu. O PSD mineiro. Belo Horizonte: Itatiaia, 1993. . Os partidos paulistas e o Estado Novo. Petrópolis: Vozes, 1980;

RICCI, Paolo (Org.). O autoritarismo eleitoral dos anos trinta e o Código Eleitoral de 1932. Curitiba: Appris, 2019. 
SILVA, Estevão; SILVA, Thiago. Eleições no Brasil antes da democracia: o Código Eleitoral de 1932 e os pleitos de 1933 e 1934. Revista de Sociologia e Política. Curitiba, v. 23, n. 56, 2015, p. 75-106.

SPINELLI, José. Getúlio Vargas e a oligarquia potiguar, 1930-45. Natal: Ed. da UFRN, 2010.

STONE, Lawrence. Prosopografia. Revista de Sociologia e Política. Curitiba, v. 19, n. 39, p. 115-137, 2011.

Artigo recebido para publicação em 04/06/2020 Artigo aprovado para publicação em 03/12/2020 